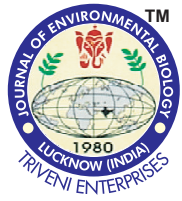

DOI : http://doi.org/10.22438/jeb/39/5(SI)/15

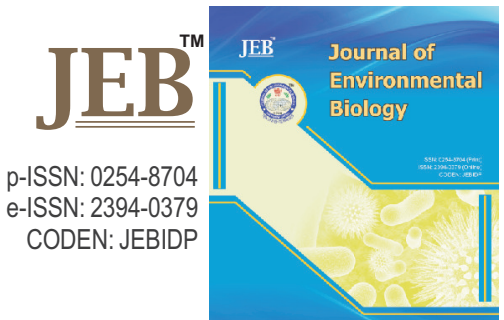

\title{
Salinity effects on the development of embryos and larvae of a high-valued sea urchin, Tripneustes gratilla (Linnaeus, 1758)
}

Authors Info

Md. Shamim Parvez', M. Aminur Rahman $^{1,2 *}$, Fatimah Md. Yusoff ${ }^{1,3}$, A. Arshad ${ }^{1,3}$ and Sang-Go Lee

'Laboratory of Marine Biotechnology, Institute of Bioscience, Universiti Putra Malaysia, 43400 UPM Serdang, Selangor, Malaysia

${ }^{2}$ World Fisheries University Pilot Programme, Pukyong National University (PKNU), 45 Yongso-ro, Nam-gu, Busan 48513, Korea

${ }^{3}$ Department of Aquaculture, Faculty of Agriculture, Universiti Putra Malaysia, 43400 UPM Serdang, Selangor, Malaysia

*Corresponding Author Email : aminur1963@gmail.com

Key words

Embryo-larva

Salinity levels

Tripneustes gratilla

Publication Info

Paper received : 22.05.2017

Revised received: 15.07.2017

Re-revised received :05.09.2017

Accepted : 28.12.2017

\begin{abstract}
Aim: To investigate the standard salinity levels on the embryonic and larval development that will be helpful for the optimum growth and larval development in the seed production of Tripneustes gratilla for aquaculture and conservation.
\end{abstract}

Methodology: Gametes were collected by injecting $0.5 \mathrm{M} \mathrm{KCl}$ into coelomic cavity of the adult sea urchin, T. gratilla and insemination was done using $10^{-5} \mathrm{~d}$ 'dry' sperm dilution from where around 500 fertilized eggs were transferred into eight transparent plastic tubes containing $50 \mathrm{ml}$ artificial seawater each with different salinities (19\%, $22 \%, 25 \% 28 \%$, 31\%, 34\%, 37\% and $40 \%$ ). To set up this experiment, $31 \% 0$ salinity was considered as a control treatment containing normal sea water. Hatching rate with required time at each salinity level were studied. Each treatment of this experiment was conducted with three replications at 26.0 $\pm 1.0^{\circ} \mathrm{C}$. All the developmental stages of embryos and larvae were observed at time intervals after insemination until attaining the metamorphic competent stage, and the duration of different development stages was also estimated.

Results: Fertilization rate was highest at $28 \%$, followed by those obtained at $28 \%, 34 \%, 25 \%, 37 \%, 22 \%$, and $40 \%$, while the lowest rate was achieved at $19 \%$ salinity level, decreased with increasing and decreasing salinities $(p<0.05)$. The development times of 16 -cell and morula stages were significantly different at $31 \%$ and $28 \%$ salinity than those at $34 \%$ and $37 \%$ salinity, whereas, in blastula, there was no significant difference $(p>0.05)$ among $31 \%, 28 \%$ and $34 \%$. The developmental times in the early prism, 2 arm and 4-arm pluteus stages showed significant differences at the salinity levels of $31 \%$ and $37 \%$. There were no significant differences $(p>0.05)$ recognized on the length and width of prism larva in these salinity levels at all. However, the differences were found to be significant $(p<0.05)$ in all the morphological characteristics of the 2and 4-armed pluteus larvae of T. gratilla.

Interpretation: To date, this is the first effort to study the influence of salinity on embryonic and larval morphometric development, and survival and growth in tropical sea urchin, T. gratilla in Malaysia. The results obtained from this study would be helpful towards the development of induced breeding, larval rearing and seed production of this high-valued sea urchins for commercial aquaculture and biodiversity conservation.

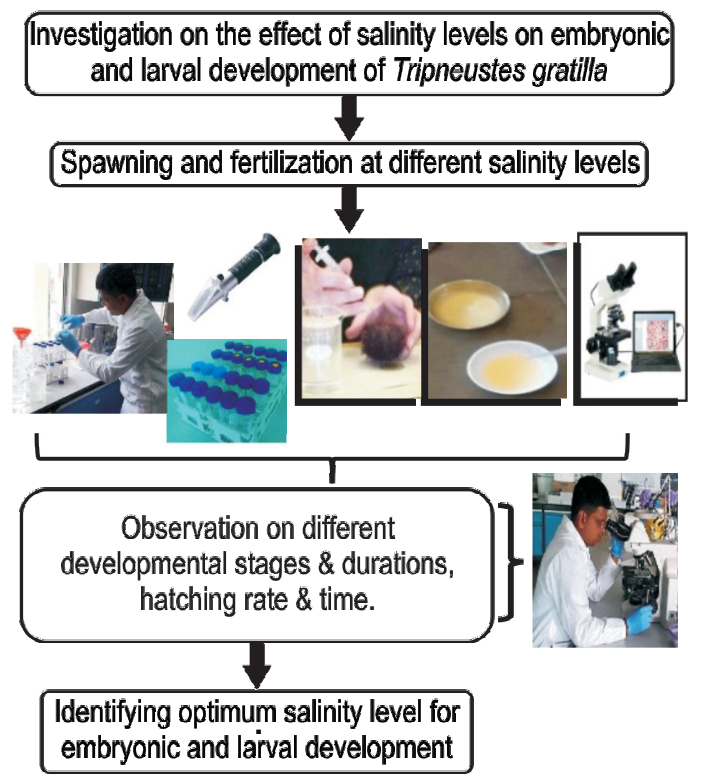




\section{Introduction}

Tripneustes gratilla (Linnaeus, 1758) (Echinodermata: Euecinodea: Tripneustidae) or collector sea urchin (Fig.1), one of the commercially important regular echinoids, has a circumtropical distributions extending into the subtropics (Lawrence et al., 2001). It occurs most abundantly throughout the Indo-West Pacific, where it can be found from east Africa (Red Sea to Natal), the south sea islands (from the Norfolk and Kermadec Islands to the Marquesas and Hawaii), and from Australia (Port Jackson on the east coast and Sharks bay on the west) to southern part of Japan (with Bonin Islands) (Lawrence et al., 2001; Lawrence, 2007). It can also be found at Pulau Bum Bum near Semporna, between Sabah and Philippines (Parvez et al., 2016a, 2016b). It is most common in very shallow water on a variety of hard substrates and is found at depths 2 to $30 \mathrm{~m}$ (Lawrence et al., 2001; Sarifuddin et al., 2014).

Echinoderms are probably the most stenohaline candidate of marine invertebrates (Stickle and Diel, 1987), possibly because they are among the poorest regular ion (Kinne, 1971). Larvae are less capable of ion regulation than adults (Kinne, 1971) and a few studies have demonstrated an unpropitious effect of decremented salinity on larval survival (Watts et al., 1982; Roller and Stickle, 1985, 1993 and 1994; Cameron et al., 1989). Stickle and Diehl (1987) suggested that the distribution of echinoderms along with salinity gradients may depend upon tolerance of the larvae.

Seawater salinity is a critical environmental factor for aquatic organism because of its importance on the development and survival of marine invertebrates (Kinne, 1964a; 1964b; Bressan et al., 1995; O'Corner and Lawler, 2004). Localized changes in coastal salinities can occur in response to warming climate as melted freshwater enters the marine environment as a source of discharge (Nihashi et al., 2005). Salinity in the Southern Ocean around Antarctica is constant throughout the year and remaining close to 34 PSU (Peck et al., 2005). In general, echinoderms are stenohaline with $99 \%$ of more than 7,000 species unable to tolerate decreasing salinity below the normal ocean levels (Stickle and Diehl, 1987; Barker and Russel, 2008) the increasing potential for lower salinities in coastal Antarctica raises questions about the salinity tolerance of echinoderms at cold polar temperatures.

The salinity acceptance of the larvae can be affected by a number of factors, the most important factors being temperature (Gray, 1976; Watts et al., 1982; Anil and Kurian, 1996) but also by length and frequency of exposure to the altered level of salinity, larval stage and/or age, and food concentration (Costlow et al., 1960; Roller and Stickle, 1993, Anil and Kurian, 1996, Richmond and Woodin, 1996).

Embryogenesis is characterized by the immediate cleavage of fertilized eggs into a greater number of small cell formations (Lepage et al., 1992). The inseminated eggs will establish fertilization envelope and undergo several cleavages including 2-cell, 4-cell, 8-cell, 16-cell stages and so on until a blastula stage (128-cell stage) is raised (Sewell and Young, 1999). During hatching, the fertilization envelope is observed to be thinner and determinately vanish as the organism secretes hatching enzyme to digest (Lepage et al., 1992). After hatching, it

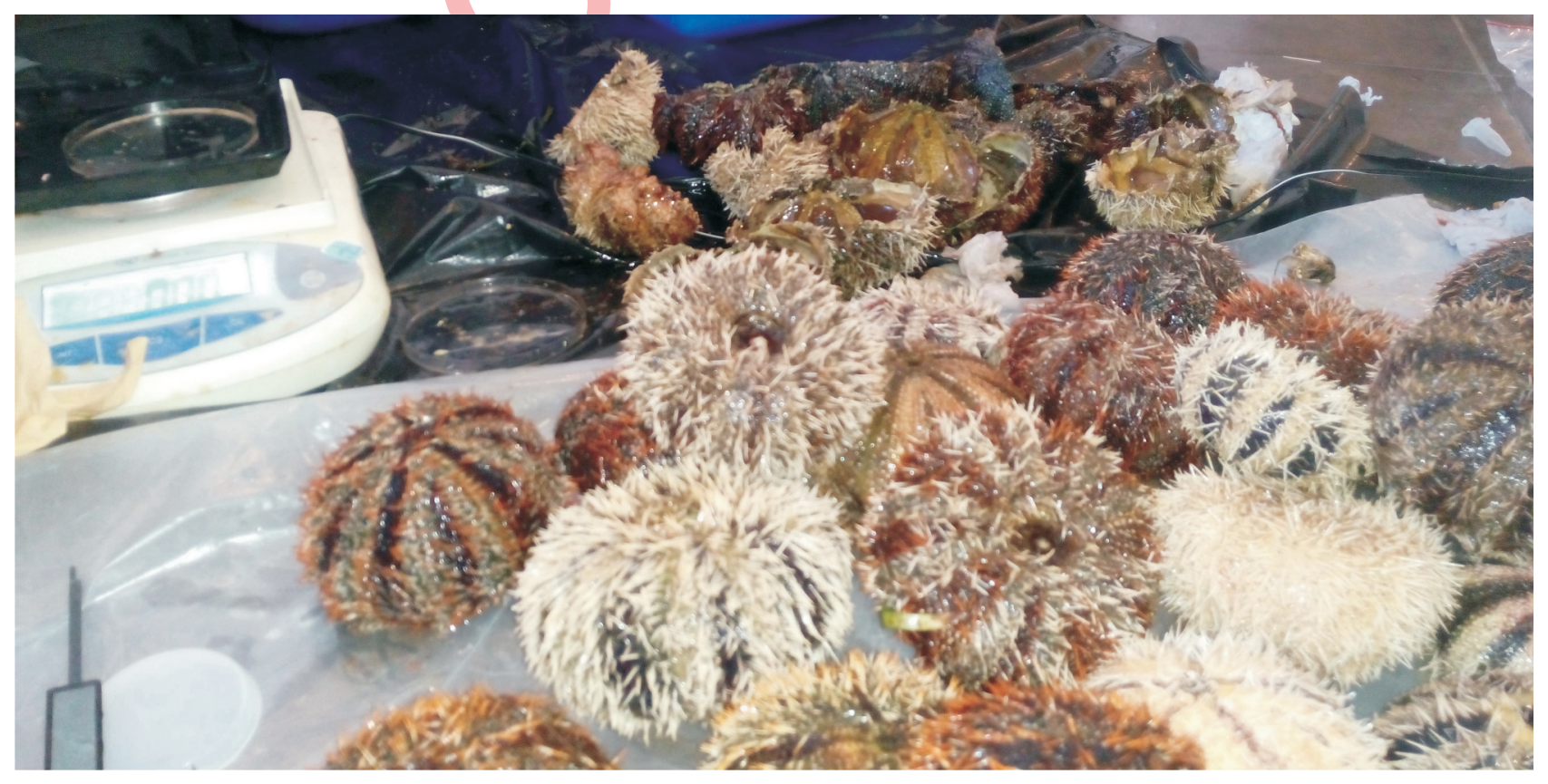

Fig. 1 : Adult sea urchin, Tripneustes gratilla 

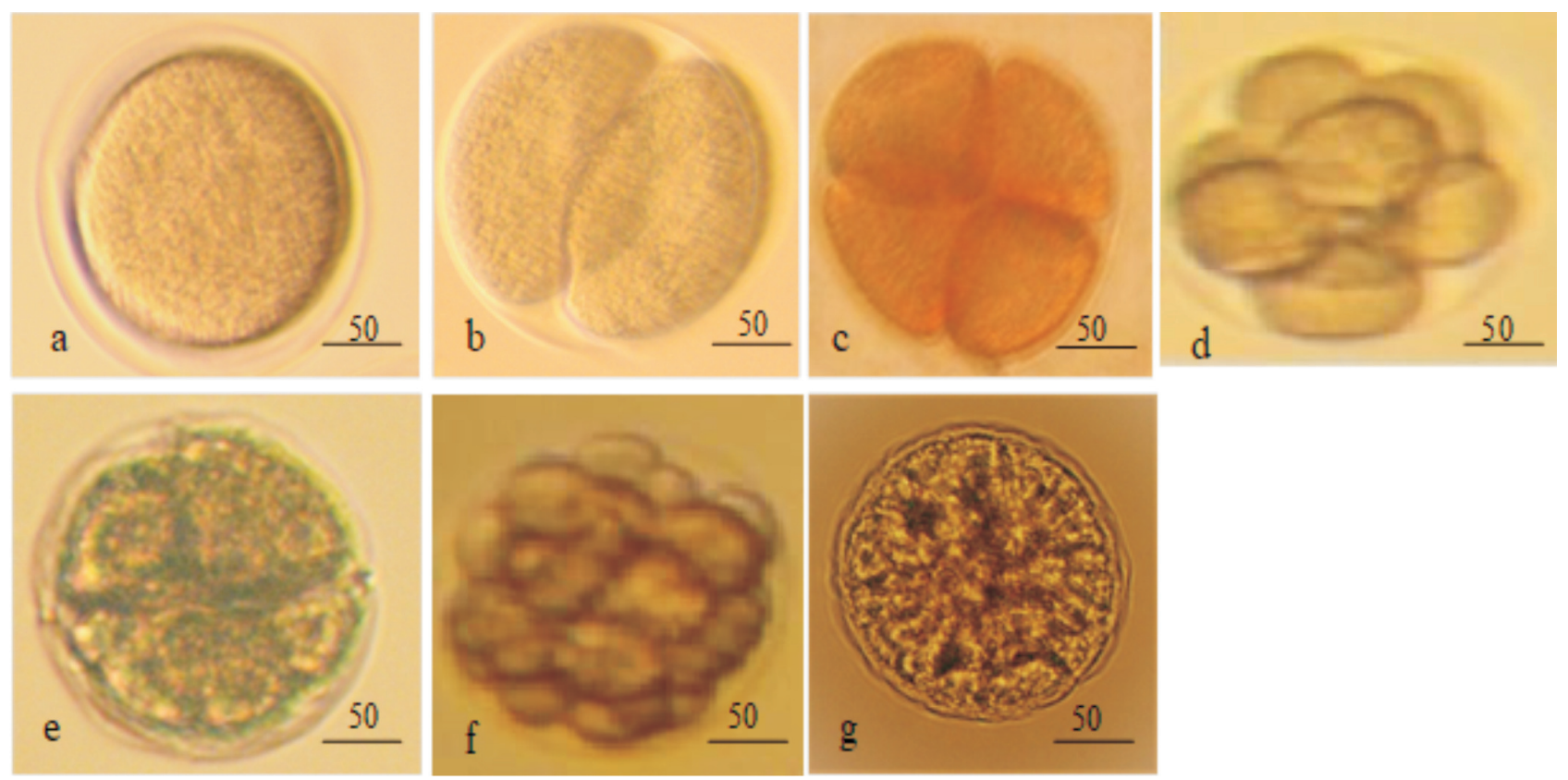

Fig. 2 : Embryonic development stages of T. gratilla under Keyence digital microscopy (a) Fertilized eggs-showing fertilized membrane; (b) 2-cell; (c) 4 cell; (d) 8-cell; (e) 16-cell; (f) Morulla and (g) Blastulla
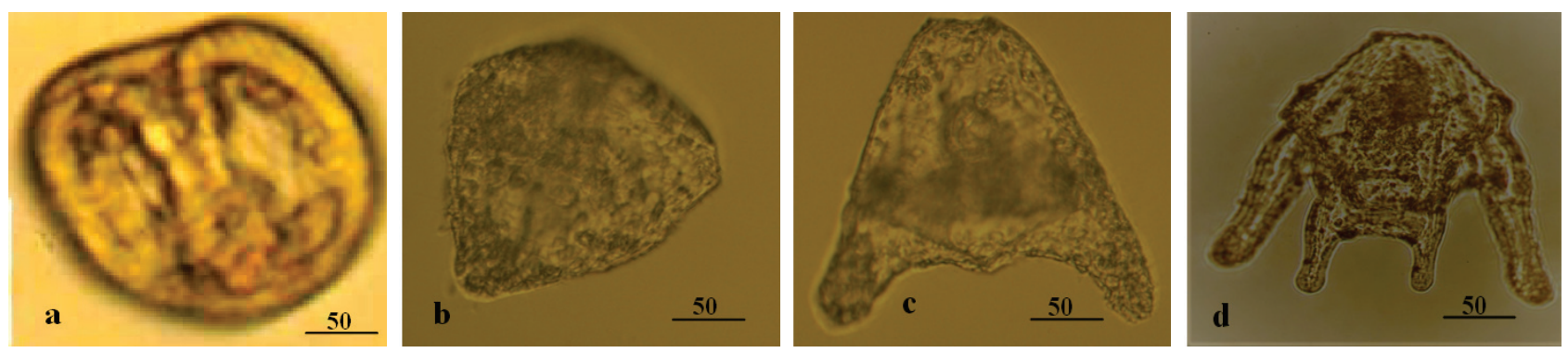

Fig. 3: Early larval stages of T. gratilla under Keyence digital microscopy: (a) Gastrula; (b) Prism; (c) 2-arm pluteus and (d) 4-arm pluteus
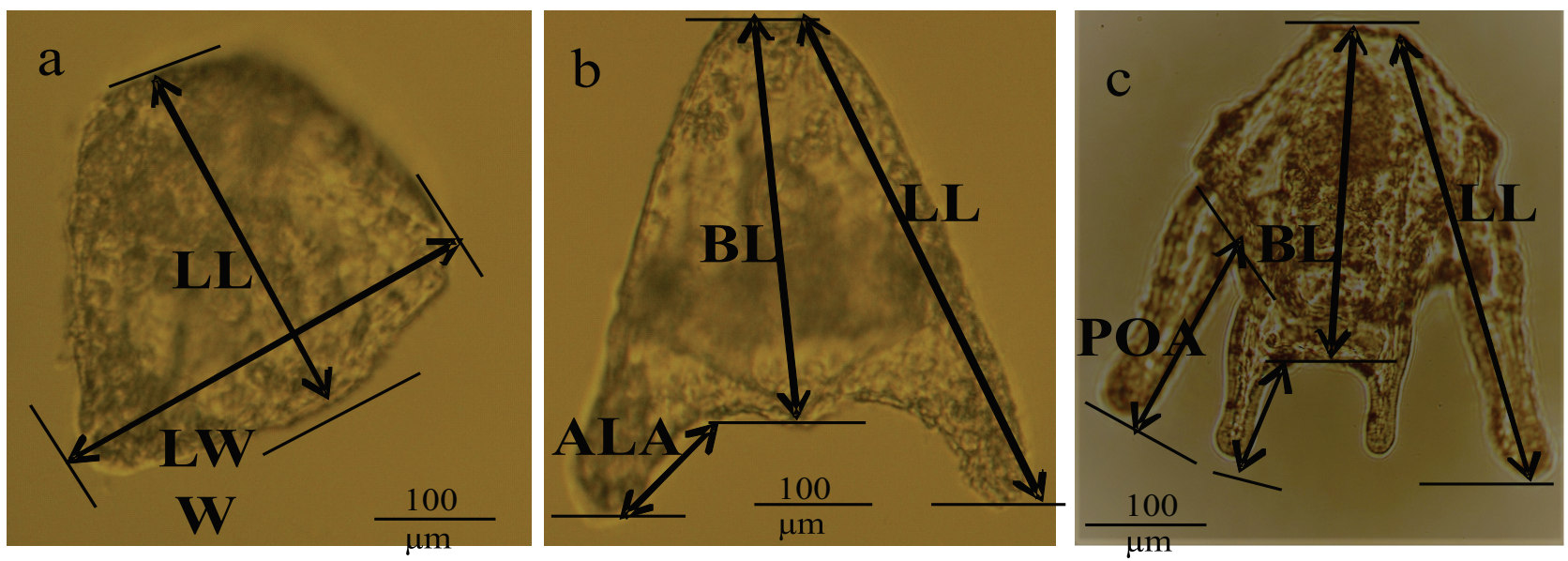

Fig. 4 : Morphometric measurements of early larval stages of $T$. gratilla under Keyence digital microscopy: $L L=$ Larval Length; $L W=L$ arval Width, $B L=$ Body Length, POA= Post Oral Arm Length, ALA=Antero Lateral Arm 
is then considered as free-swimming blastula. In gastrulation, blastula will be established to the pluteus larval stage, which subsequently exhibits sea urchins characteristics. Furthermore, during larval development, sea urchins usually pass through five stages: prism, 2-arm, 4-arm, 6-arm and end up with 8-arm pluteus (Metaxas, 1998).

For many marine vertebrates and invertebrates, coral reefs are considered to be their ideal habitat. Reproduction, development, spawning and survival of marine creatures depend mostly on the environmental parameters, viz., water temperature, salinity, pH and minerals (Alsaffar and Lone, 2000). In general, embryos and larvae exhibit lower thermo-tolerant during fertilization of gametes (Byrne, 2011). It has been stated that morphological characteristics of sea urchin larvae during fertilization process are largely affected by temperature fluctuations (Hagstrom and Hagstrom, 1959), however, the thermo-sensitivity of the embryos is different than that of their adults (Fujisawa and Shigei, 1990). It was reported that water temperature but not the $\mathrm{pH}$ shortage influences fertilization success of purple sea urchin (Heliocidaris erythrogramma), but the later development of it affects significantly (Byrne et al., 2009). Nevertheless, reduced pH level in seawater through increased concentration of $\mathrm{CO}_{2}$ was observed to decrease fertilization success and cleavage rate (Khurihara and Shirayama, 2004), as well as additionally produced larvae with smaller sizes and body compartments (Clark et al., 2009). Pagano et al. (1982) verbally expressed that exposure of sea urchin to high cadmium concentration during cleavage stage shows less impact on its development, while defection or abnormality transpires if exposure occurs after hatching.

The importance of salinity for survival and development in larvae of marine benthic invertebrates has not been established clearly. Although several studies on invertebrates have shown that deviations in salinity from ambient values can result in increased mortality and/or delayed development (Barnacles: Anil and Kurian, 1996; Crisp and Costlow, 1963; Bivalves: Bayne 1965; Calabrese and Davis, 1970; Echinoderms: Roller and Stickle, 1985, Poplychaetes: Gray, 1976; Richmond and Woodin, 1996), and others also concluded that salinity is not an important factor in determining larval survival (Young and Hazlett, 1978; Greewood and Bennett, 1981; Laughlin, 1983; Cameron et al., 1989; Pechneik, 1987).

Temperature and salinity are considered to be the most influential abiotic factors for the embryonic and early development of Paracentrous lividus (Bressan et al., 1995). It was also reported from the previous studies that salinity concentrations has profound effects on the development and survival of the sea urchin embryos and larvae (Roller and Stickle, 1993; Metaxas, 1998; Forcucci and Lawrence, 1986). Increasing salinities under same temperature have been found to affect the duration required for the embryonic development of the heart-shaped urchin,
Echinocardium cordatum (Kashenko, 2017). Mataxas (1998) found that decreasing salinities slowed down the larval development of the rock-boring urchin (Echinometra lucunter). The tolerance range to salinity levels by larvae may be wider or narrower than adults. Allen and Pechenik (2010) suggested that eggs fertilization envelope rarely elevate and even successfully fertilized eggs do not cleave at low seawater salinity. Conditions under low salinity levels decreases sighting rate, reduces magnification, and thus confines the size of the ectoderms (Forcucci and Lawrence, 1986). Lawrence (1975) reported that decreasing salinity causes reduction of viability, and thus results in mass mortality of adult sea urchin, Lytechznus varrigatus at Florida. However, such studies have yet not been carried out in the tropical species of sea urchin T. gratilla. The present research was, therefore, undertaken to examine the effects of salinity levels on the embryonic and early larval development of commercially important tropical sea urchin in a captive lab-rearing condition.

\section{Materials and Methods}

Sampling site and animal: In total, 60 mature adults of T. gratilla, weighing from 110 to $150 \mathrm{~g}$ were collected from Pulau Bum Bum $\left(4^{\circ} 27^{\prime} 55.08^{\prime \prime N}\right.$; $\left.118^{\circ} 40^{\prime} 94^{\prime \prime E}\right)$ at Semporna, Sabah between Malaysia and Philippines during their natural breeding season from October 2015 to January 2016. Soon after collection, the live specimens were transported with aerated plastic bucket to the laboratory of Marine Biotechnology, Institute of Bioscience, Universiti Putra Malaysia (UPM), where they were maintained in an outdoor tank, supplied with flow-water filtered seawater and were fed with an algal diet before use for the experiment.

Breeding protocols: After 3-4 days of sampling, sexually mature T. gratilla weighing 110 to $150 \mathrm{~g}$ were used for induced breeding. The spawning was done by injecting $2 \mathrm{ml}$ of $0.5 \mathrm{~m} \mathrm{KCl}$ into the coclomic cavity of female sea urchins. The eggs from three separate females were fertilized with sperm of three individual males. The eggs were collected by inverting the female urchins on a glass beaker filled with $2 \mu \mathrm{m}$ filtered seawater. Egg condition and maturity were checked under a compound microscope (Zeiss Axioskop 2) before fertilization. Only eggs having distinct nucleus with uniform shape were used for fertilization experiments (Rahman and Uehara, 2004). After complete shedding, the eggs were washed consecutively with filtered seawater for 3-4 times to remove the debris and immature eggs by sucking out the supernatant seawater (Giudice, 1973). Sperms from each male urchin were observed under a compound microscope to determine their motility (Rahman and Uehara, 2004). Only high motility sperms were used for fertilization trials because it can improve the fertilization success.

Fertilization of eggs: Fertilization was done at room temperature ( 26 to $28^{\circ} \mathrm{C}$ ) by pipetting few drops of diluted sperm solution into a small bowl containing eggs suspensions (Rahman and Uehara, 
2004). Sperms were left for at least 10 minutes to ensure that all the eggs were encountered by sperms during fertilization process. Excess sperms and debris were then removed from the inseminated eggs by 3 to 4 consecutive washes with FSW (Rahman and Uehara, 2004).

Rearing of embryos and larvae in different salinity treatments: Around 500 inseminated eggs were transferred into eight transparent plastic tubes containing $50 \mathrm{ml}$ artificial seawater each with different salinities (19\%, 22\%, 25\% 28\%, 31\%, 34\%o, $37 \%$ and $40 \%$ ). To set up this experiment, $31 \%$ salinity was considered as a control treatment containing normal sea water. Each treatment of this experiment was conducted with three replications. Temperature was maintained at $26.0 \pm 1.0^{\circ} \mathrm{C}$ for the entire experiment. The first 100 eggs came across were classified as 'fertilized', if they had extended 2-4 cell stage at 1.25 to $2.28 \mathrm{hr}$ post-insemination (Rahman and Uehara, 2004).

Embryonic and early larval development: Cleavage cell division and early larval stages were observed under microscope (as above) in each salinity treatment. Number of developing embryos that attained to the particular stage was determined. The percentage of development for embryos and larvae was investigated under a compound microscope (Zeiss Axioskop-2) by evaluating the time required for those stages i.e., 2-cell, 4-cell, 8-cell, 16-cell, 32-cell, morula and blastula (Fig. 2), and gastrula, 2-arm pluteus and 4-arm pluteus (Fig. 3). These were done at hourly intervals for at least $50 \%$ embryos to achieve the particular stage (Fujisawa, 1993; Rahman et al., 2002). Once the blastula attained pluteus larva through gastrula and prism stages (Fig. 3), the culture was examined daily, and numbers of larva developed into each 2- and 4-arm pluteus stage (Fig. 3) were counted by sub-sampling techniques. The time required was also estimated by the duration taken for at least $50 \%$ larva to achieve the particular stage to be completed for both developmental stages i.e., 2- and 4-arm pluteus (Fujisawa, 1993; Rahman et al., 2002).

Measurement of larvae: Regarding different salinity levels, the morphometric characteristics i.e., Larval Length ( $\mathrm{LL})$, Larval width (LW), Body (BL), Post Oral Arm (POA) and Antero Lateral Arm (ALA) (Fig. 4) of the larvae were measured and compared among the treatments. Some survived embryos and larvae at each stage under different salinities were collected and preserved in Eppendorf tube with $10 \%$ buffered formalin to investigate their formation and structures. They were placed on microscope slides with cover slip for final morphometric measurements and photographing, using a digital microscope (Keyence VH-S3OK).

Survival experiment: An experiment of survival at different larval stages (i.e., prism, 2-arm and 4-arm) was conducted in screw head falcon tube. The experimental tubes were presented at different salinity levels $(28 \%, 31 \%$, $34 \%$, and $37 \% 0)$. All tubes were kept in a water flow agitated tank for maintaining the larvae to move always. Approximately, $20-25$ nos. of larvae were placed in each test with $40 \mathrm{ml}$ filtered seawater for $2 \mathrm{hr}$ at each experimental salinity. Larvae were cultured at $28^{\circ} \mathrm{C}$ and transferred to different salinity for $2 \mathrm{hr}$. At the end of the trial, each sample was examined under a dissecting microscope and the larvae were scored as swimming or dead. Larvae that were lying at the bottom of the container, but capable of swimming if distributed, they were scored as being alive. Stages tested were swimming early prism, 2-arm pluteus and 4-arm pluteus.

Statistical analyses: The collected data on fertilization, larval development and growth performance from different salinity treatents were analysed and compared by one-way analysis of variance (ANOVA), followed by Duncan's New Multiple Range Tests (Duncan, 1955), and the level for statistical significance was set at 0.05 . All statistical analyses were performed by a computerized statistical package "SPSS" version-20.

\section{Results and Discussion}

Percent fertilization: The percentages (\%) of fertilization at different salinities are shown in Fig. 5 . The figure illustrates that mean fertilization (\%) was highest at $31 \%$ salinity followed by $28 \%$, 34\%, $25 \%, 37 \%$, $22 \%$, $40 \%$ and the lowest at $19 \%$, significantly decreased with increasing and decreasing salinity levels $(p<0.05)$. The hatching rate and the time required for hatching of $T$. gratilla at various salinities are also depicted in Fig. 5. The lowest hatching time was required at the salinity level of $31 \%$ and gradually increased with increasing and decreasing salinities. It could be observed that the successful fertilization of $T$. gratilla is largely affected by time and salinity fluctuations.

Early development: The effects of salinity on embryonic and larval development of $T$. gratilla are shown in Table 1. At the salinity levels of $19 \%, 22 \%, 25 \%$ and $40 \%$, the embryos were cleaved unequally, developed abnormally or died at the beginning of the experiment, hence these were analysed statistically. At first cleavage, larvae had attained 2-cell stage within $1.46 \mathrm{hr}, 1.25 \mathrm{hr}$, $1.31 \mathrm{hr}$ and $1.42 \mathrm{hr}$ post-insemination at 28\%, 31\%, 34\%o and $37 \%$ salinity levels, respectively. Significant difference $(p<0.05)$ were observed in 2-cell, 8-cell and morula stages, but no difference was found in 4-cell and 32-cell stages ( $p>0.05)$. The developmental time of 16-cell and morula stages were significantly different at $31 \%$ and $28 \%$ salinity than those at $34 \%$ and $37 \%$ salinity, whereas, in blastula, there was no significant different ( $p>0.05$ ) among $31 \%, 28 \%$ and $34 \%$. In early prism, 2and 4-arm pluteus stages were exposed significantly differences $(p<0.05)$ in development times at 31\%o and 37\%o salinity levels. The time taken to reach these stages increased with salinity deviations from $31 \%$ to $34 \%, 37 \%$ and $28 \%$ salinity levels. The greatest difference in developmental times were observed in 4arm pluteus, where the stage occurred within $50.24 \mathrm{hrs}, 48.59$ hrs, 49.90 hrs and 57.96 hrs at $28 \%, 31 \%, 34 \% 0$ and $37 \%$ salinity levels, respectively. 


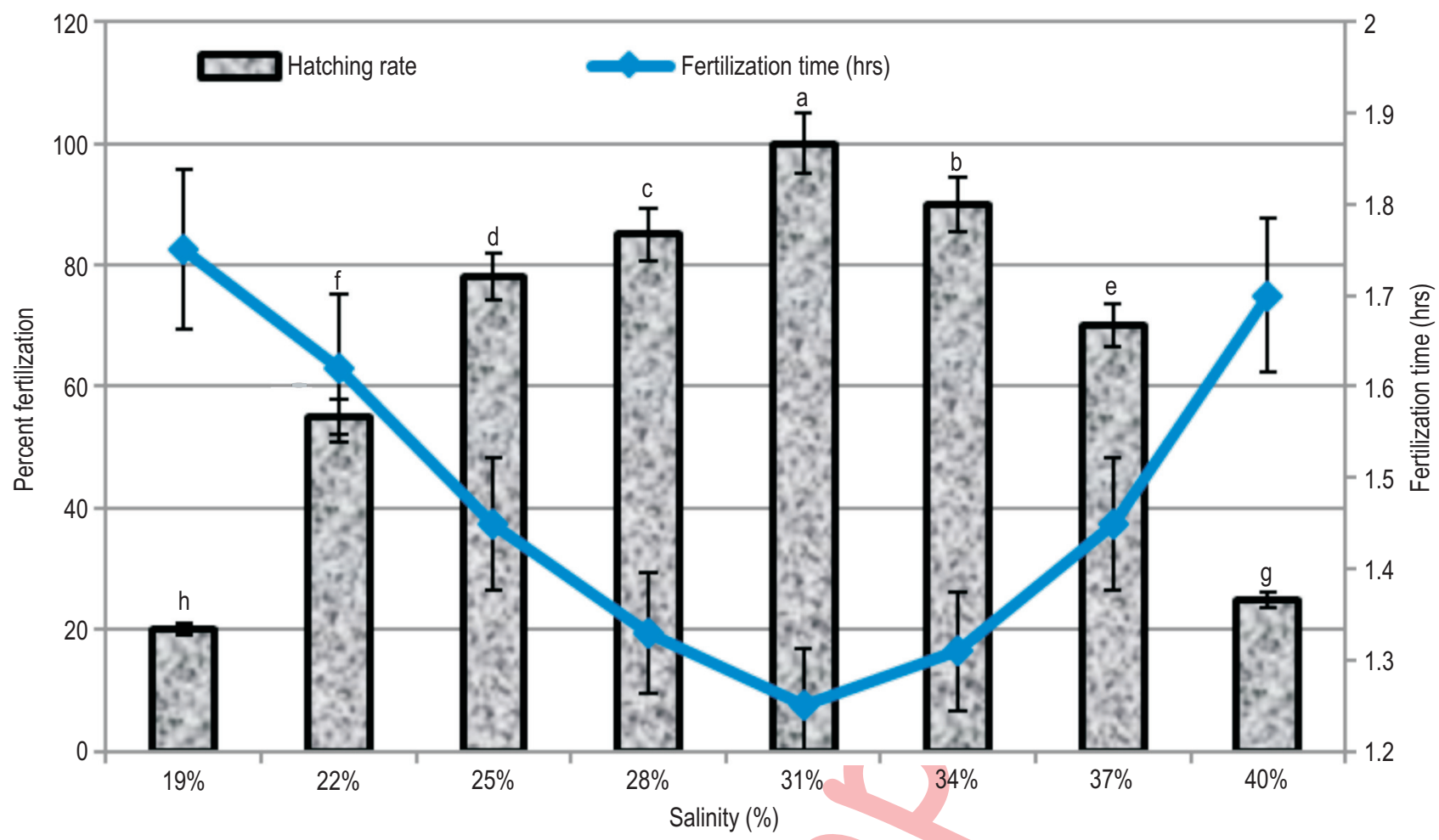

Fig. 5 : Comparison of hatching rate (\%) of eggs of $T$. gratilla at different salinity levels with required time for hatching; Columns with different letters represent means that are significantly different $(p<0.05)$; Values are mean of ten replicates \pm SE

Table 1: Effects of salinity on developmental time of T. gratilla: Time taken for $50 \%$ embryos and larvae to reach each stage. Three replicates experiments were conducted for each breeding trial

\begin{tabular}{lllll}
\hline Stages & \multicolumn{4}{l}{ Developmental time of $T$. gratilla at different salinities (\%o) } \\
\cline { 2 - 5 } & $\mathbf{2 8 \%}$ & $31 \% 0$ & $34 \%$ & $37 \%$ \\
\hline 2-cell & $1.47 \pm 0.02^{\mathrm{d}}(1.38-1.55)$ & $1.25 \pm 0.01^{\mathrm{a}}(1.22-1.30)$ & $1.31 \pm 0.01^{\mathrm{b}}(1.28-1.35)$ & $1.42 \pm 0.01^{\mathrm{c}}(1.40-1.45)$ \\
4-cell & $2.34 \pm 0.01^{\mathrm{a}}(2.29-2.41)$ & $2.28 \pm 0.02^{\mathrm{a}}(2.21-2.35)$ & $2.32 \pm 0.02^{\mathrm{a}}(2.26-2.45)$ & $\left.2.33 \pm 0.02^{\mathrm{a}} 2.28-2.43\right)$ \\
8-cell & $3.12 \pm 0.01^{\mathrm{c}}(3.07-3.20)$ & $2.36 \pm 0.02^{\mathrm{a}}(2.25-2.44)$ & $2.58 \pm 0.01^{\mathrm{b}}(2.52-2.65)$ & $3.21 \pm 0.03^{\mathrm{d}}(3.06-3.32)$ \\
16-cell & $3.41 \pm 0.02^{\mathrm{b}}(3.34-3.50)$ & $3.22 \pm 0.04^{\mathrm{a}}(3.09-3.51)$ & $4.16 \pm 0.03^{\mathrm{c}}(4.08-4.34)$ & $\left.4.29 \pm 0.03^{\mathrm{c}} 4.13-4.44\right)$ \\
32-cell & $4.51 \pm 0.16^{\mathrm{a}}(3.70-4.88)$ & $4.53 \pm 0.04^{\mathrm{a}}(4.23-4.62)$ & $4.46 \pm 0.06^{\mathrm{a}}(4.00-4.62)$ & $4.50 \pm 0.19^{\mathrm{a}}(3.42-5.45)$ \\
Morula & $4.90 \pm 0.02^{\mathrm{b}}(4.84-4.98)$ & $3.91 \pm 0.02^{\mathrm{a}}(3.82-3.98)$ & $5.82 \pm 0.07^{\mathrm{c}}(5.44-5.94)$ & $5.85 \pm 0.06^{\mathrm{c}}(5.54-5.95)$ \\
Blastula & $10.59 \pm 0.04^{\mathrm{a}}(10.35-10.75)$ & $10.52 \pm 0.07^{\mathrm{a}}(10.2-10.75)$ & $10.62 \pm 0.14^{\mathrm{a}}(10.33-11.55)$ & $11.16 \pm 0.15^{\mathrm{b}}(10.55-11.84)$ \\
Gastrula & $21.88 \pm 0.17^{\mathrm{b}}(20.95-22.54)$ & $19.99 \pm 0.16^{\mathrm{a}}(19.45-20.75)$ & $23.84 \pm 0.13^{\mathrm{c}}(19.45-20.75)$ & $25.20 \pm 0.13^{\mathrm{d}}(24.25-27.22)$ \\
Early prism & $26.67 \pm 0.04^{\mathrm{b}}(26.38-26.77)$ & $23.79 \pm 0.18^{\mathrm{a}}(23.38-24.65)$ & $27.16 \pm 0.18^{\mathrm{b}}(26.58-27.88)$ & $28.59 \pm 0.05^{\mathrm{c}}(28.42-28.87)$ \\
2-arm pluteus & $36.62 \pm 0.04^{\mathrm{b}}(36.46-36.76)$ & $34.59 \pm 0.05^{\mathrm{a}}(34.33-34.74)$ & $37.59 \pm 0.13^{\mathrm{b}}(37.46-38.65)$ & $40.44 \pm 1.00^{\mathrm{c}}(35.44-42.60)$ \\
4-arm pluteus & $50.47 \pm 0.11^{\mathrm{b}}(49.62-50.64)$ & $48.53 \pm 0.12^{\mathrm{a}}(48.32-49.30)$ & $50.52 \pm 0.38^{\mathrm{b}}(48.75-51.77)$ & $57.81 \pm 0.25^{\mathrm{c}}(57.35-59.48)$ \\
\hline Each & &
\end{tabular}

Each value indicates mean $\pm S E$ in $h r$ followed by same alphabetic superscript within the row are not significantly different at $p>0.05$

Growth performances of larvae: Effects of different salinity levels on the growth of early larval stages of $T$. gratilla are summarized in Table 2, 3 and 4. Among the treatments evaluated, only four salinity levels $(28 \%, 31 \%, 34 \%$, and $37 \%$ ) contained larvae that were still live and eventually attained to prism stage at 24 hrs post-insemination (Table 2). The highest length and width of prism larvae at $31 \%$ salinity was $116.22 \pm 1.74 \mu \mathrm{m}$ and
$77.76 \pm 0.56 \mu \mathrm{m}$, whereas the lowest values for the same were $85.70 \pm 0.41 \mu \mathrm{m}$ and $57.44 \pm 0.55 \mu \mathrm{m}$, respectively at $28 \%$. However, the differences among these four salinity levels were significant $(p<0.05)$. Morphometric comparisons of 2-arm pluteus larvae under different salinity treatments were also examined (Table 3). At this stage, larvae achieved the highest larval length $(206.22 \pm 0.41 \mu \mathrm{m})$, post-oral arm length $(88.13 \pm 0.79$ 
Table 2: Comparison of two morphometric characters of $T$. gratilla larvae at prism stage. Fifteen larvae were measured for each replicate in each treatment

\begin{tabular}{lllll}
\hline Morphometric & \multicolumn{4}{l}{ Morphometric length $(\boldsymbol{\mu m})$ of prism at different salinities } \\
\cline { 2 - 5 } Characteristics & $\mathbf{2 8 \%}$ & $31 \% 0$ & $34 \%$ & $37 \% 0$ \\
\hline Larval Length & $85.70 \pm 0.41^{\mathrm{a}}(80.65-89.45)$ & $116.22 \pm 0.74^{\mathrm{b}}(108.26-123.08)$ & $115.13 \pm 1.49^{\mathrm{b}}(100.88-130.53)$ & $86.77 \pm 0.49^{\mathrm{a}}(80.30-90.84)$ \\
Larval Width & $57.44 \pm 0.55^{\mathrm{a}}(52.23-64.38)$ & $77.76 \pm 0.56^{\mathrm{c}}(74.62-85.65)$ & $74.73 \pm 0.85^{5}(61.86-85.60)$ & $58.13 \pm 0.58^{\mathrm{a}}(52.56-65.76)$ \\
\hline
\end{tabular}

Each value indicates mean $\pm S E$ followed by the same alphabetic superscript within the same row are not significantly different at $p>0.05$

Table 3: Comparison of three morphometric characters of $T$. gratilla larvae at 2-arm stage. Ten larvae were measured for each replicate in each treatment

\begin{tabular}{|c|c|c|c|c|}
\hline \multirow{2}{*}{$\begin{array}{l}\text { Morphometric } \\
\text { characteristics }\end{array}$} & \multicolumn{4}{|c|}{ Morphometric length $(\mu \mathrm{m})$ of 2-arm at different salinities } \\
\hline & $28 \%$ & $31 \%$ & $34 \%$ & $37 \%$ \\
\hline LL(Larval Length) & $171.89 \pm 0.49^{\mathrm{a}}(164.86-178.45)$ & $206.22 \pm 0.41^{\mathrm{C}}(200.50-211.65)$ & $199.33 \pm 1.16^{b}(187.52-209.65)$ & $172.68 \pm 0.95^{\mathrm{a}}(155.68-178.89)$ \\
\hline POA(Post Oral Arm) & $69.48 \pm 0.43^{\mathrm{a}}(64.38-72.89)$ & $88.13 \pm 0.79^{b}(80.22-96.78)$ & $87.74 \pm 0.84^{b}(81.86-98.88)$ & $70.36 \pm 0.19^{\mathrm{a}}(67.65-72.55)$ \\
\hline BL(Body Length) & $114.95 \pm 0.38^{\mathrm{a}}(110.45-119.88)$ & $132.17 \pm 0.83^{\mathrm{b}}(122.42-141.65)$ & $130.62 \pm 0.60^{b}(119.67-136.56)$ & $116.42 \pm 0.48^{\mathrm{a}}(110.55-121.56)$ \\
\hline
\end{tabular}

Each value indicates mean \pm SE followed by the same alphabetic superscript within the row are not significantly different at $p>0.05$

$\mu \mathrm{m})$ and body length $(132.17 \pm 0.83 \mu \mathrm{m})$ at $31 \%$ salinity, while the lowest values of these morphometric characters were found in 2arm pluteus at $28 \%$ salinity level (Table 3). However, the differences among the salinity levels were statistically significant $(p<0.05)$. In case of 4-arm pluteus larvae, the results showed that $31 \%$ salinity achieved the highest larval, post-oral, antero-lateral arm and body length of $252.07 \pm 1.06 \mu \mathrm{m}, 133.8 \pm 0.71 \mu \mathrm{m}$, $173.46 \pm 0.96 \mu \mathrm{m}$ and $90.79 \pm 0.53 \mu \mathrm{m}$, respectively (Table 4). Among the salinity treatments, the lowest values of larval length, post oral arm length, body length antero-lateral arm length at 28\% salinity were $202.92 \pm 1.06 \mu \mathrm{m}, 121.86 \pm 0.70 \mu \mathrm{m}, 154.83 \pm 0.43 \mu \mathrm{m}$ and $62.84 \pm 0.51 \mu \mathrm{m}$, respectively. Body length and antero-lateral arm length among the four tested salinity levels were significant $(p$ $<0.5)$ (Table 4).

Survival of larvae: At different salinity level, the survival percentages of larvae (prism, 2-arm, 4-arm pluteus) are presented in Table 5. Significantly $(p<0.05)$ higher survival was observed (like fertilization rate) for larval stages of prism, 2-arm and 4 -arm pluteus of $T$. gratilla where salinity was $31 \%$. Survival rates decreased gradually, while salinity increased to $37 \%$ and $37 \%$ (Table 5). The lowest survival was counted at $28 \%$ salinity (Table 5).

Among the critical environmental factors, sea water salinity is most important for aquatic organism for the development and survival of marine invertebrates (Sarifudin et al., 2014). Until now, only few tropical sea urchins have been studied to investigate the influence of salinity fluctuations on their embryonic and larval development. The results from the previous studies have showed that larvae of many sea urchin species are stenohaline and the survival and growth pattern affected by change in salinity (Bressen et al., 1995; Cowart et al., 2009; Allen and Pechenik, 2010). In the present study, the effect of salinity on embryonic and larval development of commercially important species of tropical sea urchin ( $T$. gratilla) were throughly investigated for the first time in Malaysia. The results revealed that the embryos and larvae performed well in both development and survival rates at salinity levels between $28 \%$ and $34 \%$. Nevertheless, at salinity levels lower than $28 \%$ and higher than $34 \%$, larvae showed abnormal development or no development in rearing conditions. Similar phenomena were also observed in other sea urchin species (Roller and Sticke, 1993; Bressan et al., 1995; Metaxas, 1998; Cowart et al., 2009). Conversely, in this study, higher salinity was found to slow down the developmental rates by enhancing the duration taken for each stage to be achieved. The reason behind this might be illustrated by the adaptation of gametes to fertilize and cleave well in their naturally acclimated seawater in which $31 \%$ salinity level was more or less the same as the salinity level (28\%o) observed at the sampling site of $T$. gratilla. More research are also required to find out the exact reasons behind this. Besides, Echinoderms are usually considered as stenohaline and are confined to specific site with high seawater salinity, still some of them have been observed to occur in estuarine environments. Therefore, gametes from some species are able to adapt with the alteration of salinity concentration (Allen and Pechenik, 2010). Sarifudin et al. (2014) reported that $S$. sphaeroides was stenohaline and did not survive and develop out of 25 to $35 \%$ salinity range (Sarifudin et al., 2014). This further revealed the success of $T$. gratilla larvae to 
Table 4: Comparison of four morphometric characters of $T$. gratilla larvae at 4-arm stage. Ten larvae were measured for each replicate in each treatment

\begin{tabular}{lllll}
\hline \multirow{2}{*}{$\begin{array}{l}\text { Morphometric } \\
\text { characters }\end{array}$} & \multicolumn{4}{l}{ Morphometric measurement $(\boldsymbol{\mu} \mathrm{m})$ of 4-arm at different salinities } \\
\cline { 2 - 5 } & $\mathbf{2 8 \% 0}$ & $31 \% 0$ & $34 \%$ & $37 \%$ \\
\hline Larval Length & $202.92 \pm 1.06^{\mathrm{a}}(170.25-215.25)$ & $252.07 \pm 1.06^{\mathrm{d}}(240.44-266.86)$ & $245.77 \pm 1.31^{\mathrm{c}}(224.24-266.82)$ & $206.32 \pm 0.94^{\mathrm{b}}(195.45-215.28)$ \\
Post Oral Arm & $121.86 \pm 0.70^{\mathrm{a}}(107.38-127.76)$ & $133.86 \pm 0.71^{\mathrm{d}}(122.55-142.45)$ & $131.81 \pm 0.58^{\mathrm{c}}(120.44-135.88)$ & $124.04 \pm 0.33^{\mathrm{b}}(120.54-128.45)$ \\
Body Length & $154.83 \pm 0.43^{\mathrm{a}}(148.58-162.68)$ & $173.46 \pm 0.93^{\mathrm{b}}(162.24-184.56)$ & $172.64 \pm 0.46^{\mathrm{b}}(162.42-175.66)$ & $155.49 \pm 0.82^{\mathrm{a}}(142.78-162.65)$ \\
Anterior Lateral & $62.84 \pm 0.51^{\mathrm{a}}(52.66-66.65)$ & $90.79 \pm 0.53^{\mathrm{c}}(78.77-93.84)$ & $88.99 \pm 0.10^{\mathrm{b}}(87.62-89.88)$ & $64.03 \pm 0.49^{\mathrm{a}}(58.88-69.66)$ \\
Arm & & & &
\end{tabular}

Each value indicates mean \pm SE followed by the same alphabetic superscript within the row are not significantly different at $p>0.05$

Table 5: Survival percentage (\%) of early larval stages of T. gratilla at different levels

\begin{tabular}{lllll}
\hline Larval stage & \multicolumn{4}{l}{ Survival percentage $(\%)$ at different salinity $(\% 0)$} \\
\cline { 2 - 5 } & $\mathbf{2 8 \% 0}$ & $\mathbf{3 1} \% 0$ & $\mathbf{3 4 \%}$ & $\mathbf{3 7 \%}$ \\
\hline Prism & $72.8 \pm 0.47^{\mathrm{a}}(71.2-73.8)$ & $93.24 \pm 0.52^{\mathrm{d}}(91.5-94.7)$ & $85.94 \pm 0.39^{\mathrm{c}}(84.7-86.8)$ & $82.4 \pm 0.48^{\mathrm{b}}(80.6-83.5)$ \\
2-arm & $73.54 \pm 0.35^{\mathrm{a}}(72.4-74.6)$ & $91.9 \pm 0.41^{\mathrm{d}}(90.5-92.8)$ & $86.94 \pm 0.23^{\mathrm{c}}(86.5-87.6)$ & $82.78 \pm 0.31^{\mathrm{b}}(81.7-83.5)$ \\
4-arm & $72.92 \pm 0.40^{\mathrm{a}}(71.5-73.8)$ & $93.04 \pm 0.25^{\mathrm{d}}(92.5-93.7)$ & $87.92 \pm 0.58^{\mathrm{c}}(86.5-89.6)$ & $82.34 \pm 0.24^{\mathrm{b}}(81.7-82.8)$ \\
\hline
\end{tabular}

Each value indicates mean $\pm S E$ followed by the same alphabetic superscript within the row are not significantly different at $p<0.05$

grow and develop at $28 \%$ and $34 \%$ salinity.

Among the salinity levels, the attained length and width of prism larvae of $T$. gratilla were not significant $(p>0.05)$. Despite this, the highest values were obtained at $31 \%$. The lowest morphometric values of 2-and 4-arm pluteus larvae were found at $34 \%$ salinity level, while the highest values were achieved at $31 \%$. Roller and Stickle (1993) found that slightly higher level of salinity had resulted in abnormal development at the later larval stage of Lytechinus variegatus. Therefore, our study suggests that the growth rate of morphometric characters of 2-and 4-arm pluteus was decreasing and slowing as they may come to abnormal development or no development until the next few stages before metamorphosis. Few studied have reported that the survival and developmental rate reduces at lower salinity level (Roller and Stickle, 1993; Cowart et al., 2009; Allen and Pechenik, 2010). Nevertheless, slightly decreased salinity within the tolerance range but not at salinity extreme may improve the growth of larval length as salinity shock induces the pluteus to grow further (Sarifudin et al., 2014).

Till date, this study represents the first successful attempt to examine the impacts of different salinity levels on the embryonic, and early larval development, growth and survival of high-valued tropical sea urchins (Tripneustes gratilla) in Malaysia. The findings might eventually be helpful for the development of captive breeding and seed production of this or other commercially important sea urchin species for aquaculture development and conservation of their biodiversity to a greater extent. However, further research should be undertaken to determine the optimum salinity level within the range from $28 \%$ to $34 \%$ for the best embryonic and larval development and growth of T. gratilla in captive rearing condition.

\section{Acknowledgment}

We would like to extend our thanks to the Ministry of Science, Technology and Innovation (MOSTI), Malaysia for providing financial supports through the Research Management Center (RMC) of Universiti Putra Malaysia (UPM under the "ScienceFund" grant vide Project No. 04-01-04-SF2227 for conducting this research successfully.

\section{References}

Allen., J.D. and J.A. Pechenik: Understanding the effects of low salinity on fertilization success and early development in the sand dollar Echinarachnius parma. Biol. Bull., 218, 189-199 (2010).

Anil, A.C. and J. Kurian: Influence of food concentration temperature and salinity on the larval development of Bolamus amphitrite. Mar. Biol., 127, 115-124 (1996).

Alsaffar, A.H. and K.P. Lone: Reproductive cycle of Diadema setosum and Echinometra mathai (Echinoida: Echinodermata) from Kuwait (Northern Arabian Gulf). Bull. Mar. Sci., 67, 845-856 (2000).

Barker, M.F. and M.P. Russel: The distribution and behaviour of Patiriella mortenseni and $P$. regularis in the extreme hyposaline conditions of the Southern New Zealand Fiords. J. Exp. Mar. Bio. Ecol., 335, 76-84 (2008).

Bayne, B.L.: Growth and the delay of metamorphosis of the larvae of Mytilus edulis (L). Ophelia., 2, 1-47 (1965).

Bressan, M., M. Marin and R. Brunetti: Influence of temperature and salinity on embryonic development of Paracentrotus lividus (Lmk, 
1816). Hydrobiologia, 304, 175-184 (1995).

Byrne, M., N. Soars, P. Selyakumaraswamy, S.A. Dworjanyn and A.R. Davis: Sea urchin fertilization in a warm acidified and high $\mathrm{pCO}_{2}$ ocean across a range of sperm densities. Mar. Environ. Res., 69, 234-239 (2009).

Byrne, M.: Impact of ocean warming and ocean acidification on marine invertebrate life history stages: Vulnerabilities and potential for persistence in a changing ocean. Oceanogr. Mar. Biol., 49, 1-42 (2011).

Calabrese, A. and H.C. Davis: Tolerances and recruitments of embryos and larvae of bilave molluscs. Helgoland. Meeresunt, 20, 553-564 (1970).

Cameron, R.A., E.F. Scotte, J.B. Roy and H.D. Eric: The oral-aboral axis of a sea urchin embryo is specified by first cleavage. Printed in Great Britain @ the Company of Biologists Limited Development. 105, 641-647(1989).

Clark, D., M. Lamare and M. Baker: Response of sea urchin pluteus larvae (Echinodermata: Echinoidea) to reduced seawater $\mathrm{pH}$ : A comparison among a tropical, temperate, and a polar species. Mar. Biol., 156, 1125-1137 (2009).

Costlow, J.D. and Jr. C.G. Bookhout: A method for developing brachyuran eggs in vitro Limnology. Oceanoger., 5, 212-215 (1960).

Cowart, D.A., P.N. Ulrich, D.C. Miller and A.G. Marsh: Salinity sensitivity of early embryos of Antartic sea urchin Sterechimus neumayeri. PolarBiol., 32, 435-441(2009).

Crisp, D.J. and Jr. J.D. Costlow: The tolerance of developing cirripede embryos to salinity and temperature. Oikaos, 14, 22-34 (1963).

Duncan D.B.: Multiple ranges and multiple F. Tests. Biometrics, 11, 1-42 (1955).

Forcucci, D. and J.M. Lawrence: Effect of low salinity on the activity, feeding, growth and absorption efficiency of Luidia clathrata (Echinodermata:Asteroidea). Mar. Biol., 92, 315-321 (1986).

Fujisawa, $H$. and M. Shigei: Correlation of embryonic temperature sensivity of sea urchin with spawning season. J. Exp Mar Bio Ecol., 136, 123-139 (1990).

Fujisawa, H.: Temperature sensitivity of hybrid between two species of sea urchins differing in thermo tolerance. Dev. Growth Differ., 35, 395-401 (1993).

Giudice, G.: Developmental biology of the sea urchin embryo. Academic Press Inc. Ltd., London (1973).

Gray, J.S.: The effects of salinity, temperature and mercury on mortality of the trophophore larvae of Serpula vermicularis L. (Annelida: Polychaeta). J. Exp. Mar. Bio. Ecol., 23, 127-134 (1976).

Greenwood, P.J. and T. Bennett: Some effects of temperature-salinity combinations on the early development of the sea urchin Parechinus angulosus (Leske) fertilization. J. Exp. Mar. Bio. Ecol., 51, 119-131 (1981).

Hagstrom, B.E. and B. Hagstrom: The effect of deceased and increased temperature on fertilization. Exp. Cell Res., 16, 174-183 (1959).

Kashenko, S.D.: Adaptive responses of embryos and larvae of the hearted shaped sea urchin Echinocardium cordatum to temperature and salinity changes. Russ. J. Mar. Biol., 33, 381-390 (2007).

Kinne, $0 .:$ The effects of temperature and salinity on marine and brackish water animals: I. Salinity and temperature-salinity combinations. Oceanography and Marine Biology -An Annual Reviewer, 2, 281339 (1964a).

Kinne, O.: Non-genetic adaptation to temperature and salinity. Helgol.
Wiss. Meeresunters, 9, 433-458 (1964b).

Kinne, O.: Salinity, animals: invertebrates. In: Marine Ecology (Ed.: O. Kinne). Vol. I. Environmental factors, Part 2. Wiley, New York, pp.821-995(1971).

Kurihara, H., S. Shimode and Y. Shiayama: Sub-lethal effects of elevated concentration of $\mathrm{CO}_{2}$ on planktonic copepods and sea urchins. J. Oceanogr., 60, 743-750 (2004).

Laughlin, R.: The effects of temperature and salinity on larval growth of the horseshoe crab Limulus polyphemus. Biol. Bull., 164, 93-103 (1983).

Lawrence, J.M.: Edible Sea Urchins: Biology and Ecology. Elsevier, Boston, USA(2007).

Lawrencce, J.M.: The effect of temperature-salinity combinations on the functional well-being of adult Lytechznus varzegatus (Lamarck) (Echinodermata, Echinoidae). J. Exp. Mar. Bio. Ecol., 18, 271-275 (1975).

Lawrence, J.M. and Y. Agatsuma: Ecology of Tripneustes. In: Edible sea urchin: Biology and Ecology (Ed.: J.M. Lawrence). Elsevier Science, Amsterdam, pp. 499-520 (2001).

Lepage, T., C. Sardet and C. Gache: Spatial expression of the hatching enzyme gene in the sea urchin embryo. Dev. Biol., 150, 23-32. (1992).

Metaxas, A.: The effects of salinity on larval survival and development in the sea urchin Echinometra lucnter. Invertebr. Reprod. Dev., 34, 323-330 (1998).

Nihashi, S., K.I. Ohshima, M.O. JeVries and T. Kawamura: Sea-ice melting processes inferred from ice-upper ocean relationships in the Ross sea, Antarctica. J. Geograp. Res., 110, C02002 (2005).

O'Conner, W.A. and N.F. Lawler: Salinity and temperature tolerance of embryos and juveniles of pearl oyster, Pinctada imbricate Ro'ding, Aquaculture, 229, 493-506 (2004).

Pagano, G., A. Esposito and G.G. Giordano: Fertilization and larval development in sea urchins following exposure of gametes and embryos to cadmium. Arch. Environ. Contam. Toxicol., 11, 47-55 (1982).

Parvez, M.S., M.A. Rahman and F.M. Yusoff: Status, prospects and potentials of Echinoid sea urchins in Malaysia. Int. J. Chem. Environ. Biol. Sci., 4, 93-97 (2016a).

Parvez, M.S., A.M. Rahman, M.E. Fatimah and A. Arshad: Status, prospects and potentials of the commercially important species of sea urchin, Tripneustes gratilla (Linnaeus 1758) in Malaysia. Int. J. Biol. Ecol. Environ. Sci., 5, 50-54 (2016b).

Pechenik, J.A.: Environmental influences on larval survival and development. In: Reproduction of marine invertebrates (Ed.: A.C. Giese and J.S. Pearse), New York, New York: Academic Press, pp 551-608 (1987).

Peck, L.S., P. Convey and D.K.A. Barnes: Environmental constraints on life histories in Antarctica ecosystems: Tempos, timing and predictability. Biol Rev., 81, 75-109 (2005).

Rahman, M.A., T. Uehara and S.M. Rahman: Effects of egg size on fertilization, fecundity and offspring performance: A comparative study between two sibling species of tropical sea urchins (Genus Echinometra). Pak. J. Biol.Sci., 5, 114-121 (2002).

Rahman, M.A. and T. Uehara: Interspecific hybridization and backcrosses between two sibling species of Pacific sea urchin (Genus: Echinometra) on Okinawan intertidal reef. Zool. Stud., 43, 93-111 (2004).

Richmond, C.E. and S.A. Woodin: Short-term fluctuations in salinity: Effects on planktonic invertebrate larvae. Mar. Ecol. Prog. Ser., 
133, 167-177 (1996).

Roller, R.A. and W.B. Stickle: Effects of salinity on larval tolerance and early development rates of four species of echinoderms. Can. J. Zool., 63, 1531-1538(1985).

Roller, R.A. and W.B. Stickle: Effects of temperature and salinity acclimation of adults on larval survival, physiology and early development of Lytechinus variegates (Echinodermata: Echinoidea). MarBiol., 116, 583-591 (1993).

Roller, RA. and W.B. Stickle: Effects of salinity acclimation on larval survival and early development of Strongylocentrotus droebachiensis and Strongylocentrotus palliadus (Echinodermata: Echinoidea). Can. J. Zool., 72, 1931-1939 (1994).

Sewell, M.A. and C.M. Young: Temperature limits of fertilization and early development in the tropical sea urchin Echinometra lucunter. $J$. Exp. Mar. Bio. Ecol., 236, 291-305 (1999).

Sarifudin, M., A.M. Rahman, H.S. Yu, F.M. Yusoff and A. Arshad: Effects of salinity on embryonic and early larval development of a tropical sea urchin, Salmacis sphaeroides. Iran. J. Fish. Sci., 13, 456 -468 (2014).

Shimabukuro, S.: Tripneustes gratilla in: Aquaculture in Tropical Areas (Eds.: S. Shokita, M. Yamaguchi and M. Masashi). Midori Shobo, Tokyo, pp.313-328(1991).

Stickle, W.B. and W.J. Diehl: Effects of salinity on Echinoderms. In: Echinoderm studies, Balkema (Eds.: M. Jangoux and J.M. Lawrence). Rotterdam, 2, 235-285(1987).

Tan, L.H. and P.K.L. Ng: A guide to seashore life. Singapore Science Center, Singapore. p. 160 (1988).

Watts, S.A., R.E. Scheibling, A.G. Marsh and J.B. McClitock: Effect of temperature and salinity on larval development of sibling species of Echinaster (Echinodermaata: Aqsteroidea) and their hybrids. Biol. Bull., 1963, 348-354 (1982).

Young, A.M. and T.L. Hazlett: The effect of salinity and temperature on the larval development of Clibanarius vittatus (Bosc) (Crustacea: Decapoda: Diogenidae). J. Exp. Mar. Biol. Ecol., 34, 131-141 (1978).
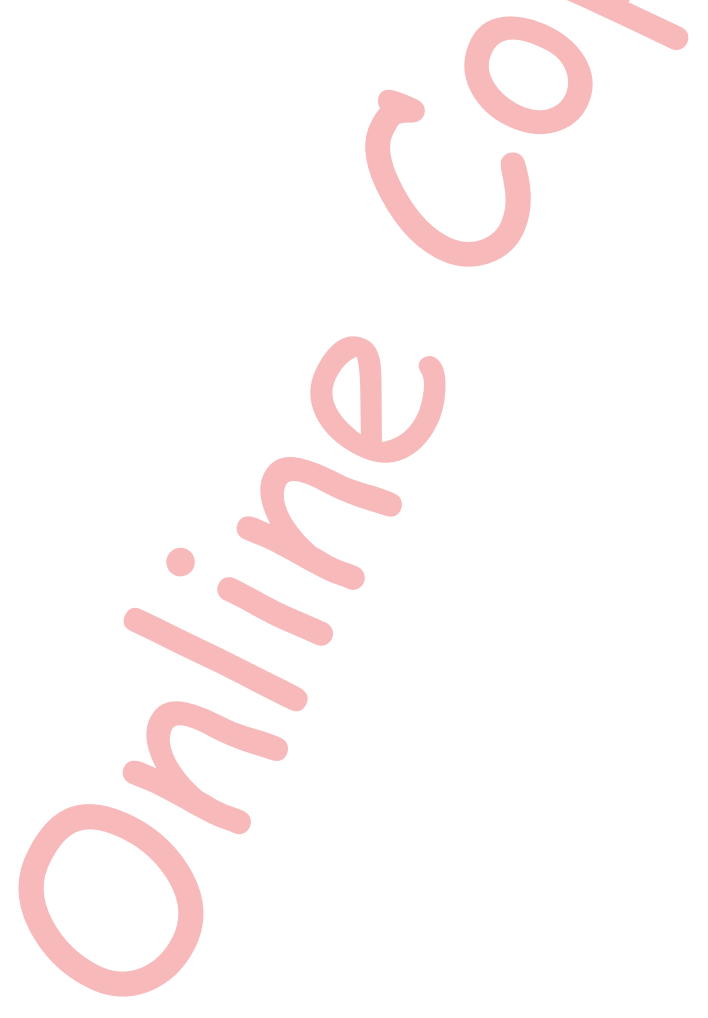